\title{
Approach to the history of bioethics in the professional education of podiatry in Spain
}

\section{Aproximación a la historia de la bió́tica en la educación PROFEsional de podología en ESPAÑA}

Daniel López López ${ }^{1 *}$, Marta Elena losa Iglesias ${ }^{2}$, Ricardo Becerro de Bengoa Vallejo ${ }^{3}$, José Ramos Galván ${ }^{4}$, María de los Ángeles Bouza Prego ${ }^{5}$, Pedro Vicente Munuera Martínez ${ }^{4}$

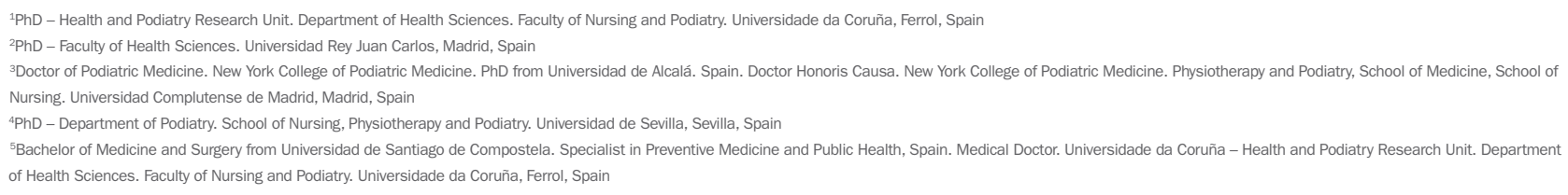

http://dx.doi.org/10.1590/1806-9282.62.01.26

Bioethics is an expanding area that contributes to the rethinking that occurred in different fields such as biology, medicine, podiatry and the environment, among others. ${ }^{1}$ The complexity of the current paradigm in the context of ethical matters, where different questions related to values, principles, norms, attitudes, rights and duties, lead to dilemmas regarding which assumption is convenient to adopt in every action. ${ }^{2}$ Ethical decisions are oriented from an anthropocentric and positive perspective to support the beliefs, attitudes and values of the human race, where the mind has superiority over biological structures and processes, as well as intelligence over morality. ${ }^{3}$ From another perspective, which we could understand as negative, the one that raises distrust and disbelief toward a group of people that contributes to scientific advancement, in order to facilitate oppression and authoritarianism. Hence, bioethics is responsible for generating synergies between Bio and Ethos fields contributing to the decision-making against the dilemmas posed by science and technology involved in matters affecting people in various spheres. ${ }^{4}$

Podiatry is involved in this issue as it participates in multidisciplinary health teams in different areas, including teaching in undergraduate, graduate and continuing education. In the research area, it is involved with innovation, development and transfer of results. In the health- care field, being in contact with the control and improving the health of people. In institutions, by giving new sustainable and healthy policies, and providing legislative codes for the profession, among other issues. Hence, bioethics is the centerpiece of study to regulate the progress of science in the field of life and health, in the light of moral values and principles based on human dignity. ${ }^{5}$

We go back to the historical background of bioethics, first mentioned by Fritz Jahr, where the link that existed between ethics and social and present morals in the professional work of those who have been devoted to health care and relationships with patients is established, making it a humanistic activity par excellence. ${ }^{6}$ Therefore, the need arises for the study of bioethics in podiatry, due to the podiatrist's holistic view in the assessment, diagnosis and treatment of the feet at a specific level, and the entire locomotor system at a general level, which allows an improvement in maintaining physical fitness and overall health in all of its dimensions: biological, psychological and social. ${ }^{7}$ In addition, the importance not only of medical problems but also of ethical issues, together with the improvements in biomedical advances, the complexity of podiatric activity, economic and workload pressure, has led to an increased demand for the podiatrist, where often the demands and prioritization of ethical issues are experienced, being a necessary component of clinical practice. ${ }^{8}$ 
While podiatry students pay little attention to ethics, which are determined by knowledge and the experiences acquired, ${ }^{9}$ one must consider that bioethics is learned, in the context of contemporary education, ${ }^{3}$ which will work as a facilitator for the podiatrist, contributing with podiatrist studies to reach special awareness in aspects related to the environment, sustainability, biodiversity, plurality and a wide part of everything else in the world.

The lack of strategies to deal with a podiatrist's ethical dilemmas, ${ }^{10}$ show the student's interest in bioethics and ethical issues that result in internalization to form a moral conscience, making it easier to deal with moral distress and ethical dilemmas and enabling a continuum where paradigms are exposed using different methodologies, such as case discussion aiming at a debate between students and the lecturer, as a part of the teaching/learning method, to establish and recognize the ethical and the unethical and contribute to an improvement in the teaching/learning process, where education in bioethics should enable students to increase their respect for human dignity and life. ${ }^{3}$

Therefore, the formation of a podiatrist has to establish an overall additional education oriented towards social problems, biodiversity, solidarity, principles, values, and caring for others and oneself, which should enable future specialists to solve the ethical problems that arise in the activity of care. ${ }^{8}$ In particular, bioethics will be a facilitator in the educational action, able to guide the student to resolve conflicts and acquire the necessary skills to be a good professional. ${ }^{11}$

To do this, podiatry students must receive information based on educational aspects to help develop a comprehensive and broad vision, in which there is no prejudice related to ethical dilemmas to offer the necessary guarantees in different job opportunities specific to the career, focused on teaching, research, management, clinical practice, and more.

The podiatrist must have special interest in social priority areas such as poverty, hunger, injustice, violence and corruption, so as to address inequality, pain and suffering of the disadvantaged. The participation of the podiatrist when it comes to defending the rights of patients and of individuals must be a competence to manifest at a general level as part of the multidisciplinary health team, pointing out competences and ethical norms, especially when directly receiving patients.

The identification carried out by podiatrists and medical personnel of a number of ethical problems related with moral distress, task organization, patient demands, time constraints, a lack of human resources, the dilemmas of aging, pain, death, palliative care, euthanasia, the right to die with dignity, wealth distribution, protection of patient autonomy, investigation, the podiatrist-patient relationship, informed consent, confidentiality, honest communication with patients, responsibility of health professionals and patients, and humanization of care, which together with the lack of strategies to address the priority related to the relevance of moral dilemmas, illustrate the need for answers on common aspects of everyday practice, to facilitate the activity of the podiatrist. ${ }^{12}$

Evolution, in Spain, of the profession of podiatry is the result of the institutional and legislative framework, and social demand, given the lack of specialized care for foot health, which was seen before the appearance of this health discipline. ${ }^{13}$ Obtaining specific legislation allows the determination of disciplinary measures by podiatrists to safeguard both the profession and patients.

The Spanish law governing health professions defines the profession of podiatry as: "doctors who perform activities aimed at diagnosing and treating diseases and deformities of the feet, through their specialty techniques". The law endorses the disciplinary problems regarding ethics will be addressed by the General Council of each profession (in this case the profession of podiatry), which applies its own sanctions under their particular code of ethics, regardless of any other civil or criminal sanctions that Spanish courts can apply to these types of offences. ${ }^{14}$

For example, Article 1, Section 7 of the Code of Ethics of the Spanish podiatrists states that: "Podiatrist in their professional activity shall scrupulously respect the right to freedom, dignity and privacy of individuals, without prejudice as to race, gender, religion, political beliefs, or any socio cultural condition of the patient" and paragraph 7: "Members who infringe professional duties related to this Code of Ethics for Podiatry, or particularities of each school, may be subject to disciplinary action in accordance with their own statutes". ${ }^{15}$

Therefore, synergies between professional training in podiatry and ethics are of vital importance in the context of higher education, being the faculties of podiatry responsible for implementing programs that contain a holistic and biopsychosocial view, where the domains of humanities, biomedicine, technologies and other are presented to students graduating in the specialty with the purpose of developing and enhancing expertise in ethics to improve decision-making and professional ethics.

The changes that have taken place in European education created a new European Higher Education Area, so that the transformation of Spanish titles involves their generalization in order to facilitate the free movement and exchange of students and graduates among countries. ${ }^{16}$ The uniformity of the studies podiatry in Europe, 
together with new official postgraduate programs, are an incentive for the development of ethical issues and professional ethics in the curriculum, contributing to increased knowledge in Europe of podiatry students in the areas of bioethics, ethics and deontology.

\section{REFERENCES}

1. Cristina J. Campos de reflexión. En: Elbert L, ed. Bioética: compromiso de todos. Montevideo: Ediciones Trilce; 2003. p.9

2. Escobar Triana JA, Aristizábal Tobler C. Los principios en la bioética: fuentes, propuestas y prácticas múltiples. Revista Colombiana de Bioética 2011; 6:76-109.

3. Losa Iglesias ME, Becerro de Bengoa R. History of bioethics in professional nursing education: a spanish view. Acta Bioeth. 2013; 19(2):293-297.

4. Lolas F. Acta Bioethica: expansión de su ámbito temático. Acta Bioeth. 2013; 19(2): 175

5. Pardo Sáenz JM. Bioética práctica al alcance de todos. Madrid: Ediciones Rialp; 2004. p.16.

6. Lolas F. Bioethics and animal research: a personal perspective and a note on the contribution of Fritz Jahr. Biol Res. 2008; 41(1):119-123.

7. López López D, Ramos Galván J, Alonso Tajes F, García Mira R. Manual de Podología: conceptos, aspectos psicológicos y práctica clínica. Madrid: CERSA, 2012. p.18.
8. Losa Iglesias ME, Becerro de Bengoa R, Salvadores P, Trepal MJ. Comparative analysis of moral distress and values of the work organization between American and Spanish podiatric physicians. J Am Podiatr Med Assoc. 2012; 102(1):57-63.

9. Moreno de la Fuente JL. Podología: emprendimiento, ética, legislación y gestión. Madrid: BDS Librería Editorial; 2013. p.151.

10. Losa Iglesias ME, Becerro de Bengoa R, Salvadores P. Moral distress related to ethical dilemmas among Spanish podiatrists. J Med Ethics. 2010; 36(5):310-4.

11. Losa Iglesias ME, Becerro de Bengoa Vallejo R, Palacios Ceña D, Salvadores Fuentes PS. Knowledge and positions on bioethical dilemmas in a sample of Spanish nursing students: a questionnaire study. Contemp Nurse. 2011; 38(1-2):18-23.

12. Losa Iglesias ME, Becerro de Bengoa Vallejo R. Musculoskeletal pain, job satisfaction, depression, and anxiety among spanish podiatric physicians. J Am Podiatr Med Assoc. 2014; 104(2):191-7.

13. López López D. Podología y salud: un análisis de las representaciones sociales de las enfermedades del pie desde una perspectiva psicosocial. A Coruña: Servizo de Publicacións da Universidade da Coruña; 2011.

14. Boletín Oficial del Estado. Ley 44/2003, de 21 noviembre, de ordenación de las profesiones sanitarias. Disponible en: http://www.boe.es/buscar/doc php?id=BOE-A-2003-21340. Consultado el 15/09/2014

15. Código Deontológico de Podología. Madrid: Consejo General de Colegios Oficiales de Podólogos; 2014

16. Tejeiro Salguero R, Gómez Vallecillo JL. El sistema educativo español: estructura y funcionamiento. Málaga: El Gato Rojo; 2012. 